\title{
Meaningful learning and the teaching of concepts in Physical Education in school: a case study with the Olympic Games
}

http://dx.doi.org/10.11606/1807-5509201800020219

\author{
Natália Kohatsu QUINTILIO * \\ Osvaldo Luiz FERRAZ*
}

*School of Physical Education and Sport, University of São Paulo, São Paulo, SP Brazil.

\begin{abstract}
The aim of this research was to investigate the influence of an instructional planning based on assumptions of the meaningful learning, from principles of Joseph D. Novak's Educational Theory, using concept maps and other teaching resources in the learning of concepts in physical education classes. Students made a pre-and post-intervention concept map. The analysis of the results showed that there were improvements in the concept maps' quality and in the understanding of concepts related to the Olympic Games, organized under the Educational Theory principles of Novak and that new teaching and learning tools should be part of physical education classes.
\end{abstract}

KEYWORDS: Educational theory; Concept maps; Novak's Theory of Education; Learning tools.

\section{Introduction}

Every educational practice in school can be understood as a tool that enables members of a society to assimilate the cultural foundations necessary for the socialization and individualization processes and, therefore, knowledge needs to be planned in educational activities ${ }^{1}$.

Thus, schooling consists of activities whose purpose is to help students assimilate some cultural foundations considered essential for their development and socialization, implemented in accordance with a given planning, i.e., based on an educational project.

According to NovaK ${ }^{2}$, the main goal of school education is to empower students to take an active role in learning, which involves thinking, feeling and acting and, these three aspects, should be integrated to meaningful learning and, especially, to the creation of new knowledge. According to the author, acquisition of knowledge, change in emotions or feelings and physical and motor improvement, combined, help humans to make sense to their experience.

To Joseph Novak, the need for a new educational theory was due to the understanding that education is a complex human effort to understand that an educational theory is essential to plan and guide new pedagogical practices. In his Theory of Education, the author argues about the ineffectiveness of mechanical learning for the retention of long-term knowledge and its application in the daily life and therefore, contrasted to meaningful learning, which basis is the constructive integration of thinking, feeling and acting, seeking empowerment, which means that the individual realizes he is capable of learning. According to NovaK ${ }^{2}$, there are five key elements in education: student, teacher, knowledge, context and evaluation that together, lead to honest, authentic and productive educational outcomes. According to Ausubel, NovaK and Hanesian ${ }^{3}$, there is an intimate relationship between discovering how students learn and figuring out what to do to help the student to learn better. Through teaching, one intends to guide the learning processes through actions suggested by an educational theory. Thus, it would be reasonable to assume that the use of more effective teaching methods should depend on and relate to a learning theory.

Meaningful learning is the central idea of Ausubel's Learning Theory, defined as a process in which new information is related to an existing one present in the cognitive structure and, from this point of view, creativity is seen as a result of the higher level of meaningful learning, and the creation of new knowledge in a constructive process that involves knowledge and emotions $s^{4}$. The mechanical 
learning is the process of learning in which the student memorizes the information without giving meaning to it. From the strictly mechanical learning to highly meaningful learning, there is a continuum, which does not characterize them as dichotomous.

According to $\mathrm{NovaK}^{2}$, for meaningful learning to occur, three conditions are required: structured and relevant prior knowledge, potentially significant instructional material, and the student's desire to learn meaningfully.

Prior knowledge is one of the axis of meaningful learning, and integrating it with the new concepts is given by the subsumption process, i.e., when a less inclusive concept connects to a more inclusive concept and both are modified. When acquiring new meanings, existing concepts become differentiated, more stable and hierarchically organized. The potentially significant instructional material must be conceptually clear, and presented with language and examples relatable to the previous knowledge of the student. In regards of the disposition of learning meaningfully, it is a personal, conscious, and deliberate choice to relate new knowledge to the existing one. This is the only condition on which the teacher has no direct control, since it is an intrinsic motivation ${ }^{2}$.

Concept Maps (CM) are graphical teaching, learning and evaluation tools that organize and represent knowledge, including concepts and their relationships. The former are usually represented within squares and the relationships by lines that connect them, which are important to show what was understood from the relationships between concepts. CMs are characterized by their hierarchical structure, their ability to seek and characterize new crosslinks and by specific examples that help to clarify the meaning of a particular concept ${ }^{4}$.

To Cañas and NovaK ${ }^{5}$, using CM only as an evaluation tool is to reduce its potential as a tool. However, according to the authors, at some point, its quality needs to be evaluated, and what it informs is only part of the educational process. According to the authors, the graphic nature of CMs allows a topological, structural and therefore objective analysis. The hierarchical structure of knowledge generally produces $\mathrm{CM}$ with the more general concepts at the top and, those more specific at the bottom. Regarding the content, one should pay attention if it responds the focal question, i.e., the main question of the problem or issue to be resolved. A good CM will answer this question clearly. The conceptual content and propositions can be assessed by parameters such as fullness (if there is any missing key concept), quality and relevance (the chosen concepts are suitable, appropriate and relevant to answer the focal question?).

The graphical analysis of content and interaction between them expresses the student's understanding of a particular topic ${ }^{5}$. However, teachers need to understand that the type and quality of CMs should be more a reflection of the learning process and the conditions under which each of them was built than the exact understanding on the subject, i.e., frequently what the student really knows cannot be expressed on the map.

NovaK $^{2}$ points out that once the students acquire skills and experience in building CM, and reported to be learning how to learn, which makes $\mathrm{CM}$ a powerful metacognitive tool. Metacognition is defined as a multidimensional framing that includes knowledge and control of cognitive processes (WITtrock $\left.\operatorname{apud}^{6}\right)$. It has become an important subcategory in education since it allows the self-learning and the control of learning relate to the learn autonomy ${ }^{7}$. According to the author, students became better in meaningful learning and realized that they could reduce or even eliminate rote learning. Therefore, $\mathrm{CM}$ enhanced empowerment, i.e., collaborated with control over what they learned and how they used the new knowledge.

Ferraz and MaCEDo $^{8}$ propose that, in addition to providing sports programs and physical activities in general, physical education classes should provide students with knowledge to assess their health and wellness and ability to be a critical consumer of physical activity practices (olympic games, sports, dance, gymnastics, contest practices, among others), and information published by various communication channels about them. However, the knowledge required to take advantage of these physical activity practices should rely on conceptual elements and practical experience.

Thus, the role of the physical education teacher in school is to develop, implement and evaluate programs including games, sports, wrestling, gymnastics, dance, exercise, among others, with implicit and explicit educational objectives ${ }^{8}$.

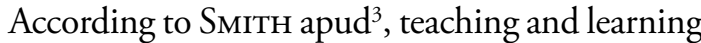
are extensive processes. Therefore, although it is true that teaching and learning are different notions and can be analyzed separately, what would be the advantage of the separate analysis, since facilitating learning should be one of the purposes of education?

Thus, studies that coordinate the actions of teachers and students, linking them to the content through the processes of teaching, learning and evaluation are 
important for education. Moreover, in the educational process, it is necessary to value students' understanding on the importance of learning certain content and how they can make use of this content to help them become active humans in the environment where they live.

The characterization of school knowledge can be done by learning concepts, procedures, feelings, values, norms and attitudes, which refer to large areas of human development. This knowledge is organized into contents, usually pertaining to a discipline, including physical education; however, it is worth remembering that they should not be studied in a disconnected manner.

This article describes a study that focuses on the conceptual content of physical education in school, which does not mean that other dimensions (procedures, feeling, values, norms and attitudes) are unimportant or would no longer be worked; after all, the choice of the Olympic Games as a content block also implies the presence of procedures, standards and values in the teaching and learning process.

The Olympic Games, the public facet of the Olympism and the major event in the planet, represent one of the most visible activities of the sportive background. The Olympism is a philosophy of life based on the balance between the body, spirit and mind and, whenever inserted into the school context generates what some authors denominate the Olympic Education'. For MüLleR ${ }^{10}$, the Olympic Education is characterized by: a harmonic development of the human being, the search for perfection, sportive activity linked to ethical principles, concepts of peace and goodwill between nations and emancipation into and through the sports.

For MÜLLER ${ }^{10}$, the harmonic and integral development of the human being points out that the education is not concentrated only in the mind and in intellect, but in the body as well. Children and young people need to be more aware that the sports must be part of them as human beings.

According to Perez et al. ${ }^{9}$, there are several pedagogical approaches of the Olympic Education in the worldwide scenario.

For example, Gessman (1992, apud ${ }^{9}$ ), the core of the Olympic values system is the constant development of the potential of each human being and, in this way, he emphasizes sports in school and suggests four areas of learning: fair play, health, adventure, artistic and creative development and sociability.

$\operatorname{KIDD}\left(1985\right.$, apud $\left.{ }^{9}\right)$ articulated Olympism and the general objectives of education through some points such as participation in collective activities, sport as education, sporting spirit, cultural exchange, international understanding and Excellence.

In Germany, Gruepe (1996, apud ${ }^{9}$ ) establishes three pedagogical objectives for Olympic education: (1) development of the body, mind and character through an effort to perform physical activities and competitions; (2) availability of a variety of sports and (3) peace and international understanding.

To plan a consistent instruction based on the Novak's Theory of Education, the first task is to identify the basic concepts of the subject and how they are structured. After that, one must pay attention to the sequence of activities to ensure that these concepts are present in the cognitive structure of students and serve as previous organizers for future learning. Ferraz and Belhot ${ }^{7}$ agree with Moreira and MAsin I ${ }^{11}$ when stating that understanding the concepts is progressive and possible within a coherent curriculum, promoting a shift from a structure to another and not replacing a concept by another.

The idiosyncratic factor must be taken into account when thinking about the concepts that will constitute the subsumers for a new subject. Considering only the denotative meaning of the concept can run the risk of failing to consider one of the key points that supports the Ausubel's theory of meaningful learning, in which the concepts are the result of experience and are phenomenological products. Thus, the individual is active and the situation in which experience and personal development involve cognition and connotation ${ }^{12}$.

If the construction and correction of evaluation tools are important, how teaching and learning are developed in daily life is essential. NovaK ${ }^{2}$ states that teaching is a complex activity and believes that this act should be guided by an educational theory. Moreover, meaningful learning is an activity which responsibility cannot be shared, as it is dependent on the willingness of each to do it this way. Teaching, thus, depends on a negotiation of meanings between teachers, students and a favorable emotional environment. So, meaningful learning depends on a good teaching strategy; however, for it to actually occur, motivation to learn must come from the student.

The approach of the theory to pedagogical actions seem consistent for anyone who has, as main activity, teaching. The interdependence between the content to be taught, educational activities and subjects involved in the educational activity is one of the problems of pedagogical action. The guiding teaching activities proposed by Moura et al. ${ }^{12}$ will 
be the link between Novak's Educational Theory and educational activities, as they include the interaction between student and teacher, key elements for learning to occur, preferably meaningful.

Moura et al. ${ }^{12}$ states that guiding teaching activities involve learning contents, students and teachers, promoting culture appropriation and human development. In this way, they acquire a dimension of mediation, as they are a way of performing teaching and learning, modifying the subjects involved. Thinking what activities lead students to access theoretical knowledge and develop their higher mental functions is the practical character of one of the points that Ausubel considers essential to meaningful learning select potentially meaningful material.

If the guiding teaching activities are a process aimed at the acquisition of knowledge, their main goal is "to provide the need for ownership of the concept by the student, so that his actions are carried out in search for the solution of a problem that leads him to the learning activity" ${ }^{\prime 2}$ (p. 101). The connection with the Novak's Educational Theory is done with the condition of meaningful learning, in which the learner must be willing to acquire meaningful learning ${ }^{4}$.

The last condition is that the student should have relevant prior knowledge, with which the new material can be related. Moura et al. ${ }^{12}$ states that in the guiding learning activity, both the student and the teacher have prior knowledge, values and affection that will affect the way they will carry out the actions aimed at a knowledge of new quality. Understanding that the content of education, educational activities and subjects (student and teacher) are interdependent and are part of the educational activity is one of the key points of pedagogical action.

It is known that physical education, while a discipline inserted in the Brazilian school curriculum, goes beyond the teaching of motor skills and improvement

\section{Method}

Participants were $493^{\text {rd }}$ graders from a public elementary school in a city of São Paulo's great ABC region. The study was approved by the Ethics Research Committee and registered in Brazil Platform (No. CAAE 08228712.6.0000.5391, November, $30^{\text {th }}$ 2012). Parents and/or guardians signed the informed consent form authorizing participation in the research. of physical abilities, as it demonstrates potential to integrate cognitive, affective and motor aspects by learning a set of codes and social and scientific productions of humanity, which characterize the physical activities practices aimed at the promotion of health, leisure and communication.

Thus, it is understood that physical education can use the Novak's Theory of Educational because the content of the discipline, which should be the know-how and knowledge about physical activities, includes thinking, acting and feeling, i.e., the pillars of meaningful learning. This learning seeks empowerment, leading the student to realize that he is capable of learning. This condition, known as metacognition, can be beneficial at any time in the student's life, whether in school or outside the school.

Although several investigations in schools have produced interesting results in the perspective of the use of concept maps in formal education as a teaching strategy and assessment, according to ToIGo, MoreIrA and $\operatorname{Costa}^{13}$, until 2010 there were more than 200 articles published from 26 countries, including the United Studies and Brazil, leaders with respectively 64 and 26 articles. The authors did a literature review of articles in national and international journals and record of the I, II and III International Conferences of Concept Mapping. With regard to the education level, the higher education leads, followed by the elementary school and about the area of concentration, most of the articles were related to the study of sciences, and only three were about physical education, which emphasizes the relevance of the present study.

Thus, the purpose of this research was to investigate the influence of an instructional planning based on assumptions of the meaningful learning, from principles of Joseph D. Novak's Educational Theory, using concept maps and other teaching resources in the learning of concepts in physical education classes.

Interventions in regular teaching period were performed by the teacher / researcher which involved lectures, multimedia support such as video and computers, CmapTools software, group discussion and practical activities, whose aim was to diversify the teaching resources and meet the demands for meaningful learning. 
- Class 1: CM construction;

- Class 2: Class about Olympism. In pairs, the students read a text and select 10 important concepts to explain the Olympism;

- Class 3: Class about ancient Olympic Games and the Olympic Games of the modern era. Students should think of athletes who were part of the Olympic Games of the modern era and, as homework, research an Olympian;

- Class 4: Class about Olympic symbols. It was presented to the students a CM about the Olympic symbols. They should choose one symbol and transform the preposition in a sentence;

- Class 5: Class about rules and values. The students will apply values of Olympism, such as friendship, justice, fair play, and respect to play dodgeball;

- Class 6: Class about values. Class begins with the question: what are the values in sport? Videos about fair play including "celebrate humanity", produced by COI. The students should think about how they could use these values on a daily basis to improve coexistence with society

- Class 7: CM construction post-intervention.
The CM was aimed to verify changes in the way children understand the concepts studied. The focal question of the CM studied was "What comes up to my mind when I think of the Olympic Games?", and identical pre and post-intervention CM were applied. The comparison of them were made by the researcher.

The analysis of the CM, made from the premise that, in addition to testing knowledge, it should serve to inform the student's learning process (what does he know, his mistakes and difficulties) regarding the study content. The criteria described by Cañas and NovAK $^{5}$ were used, namely:

- Graphical nature: it checks if there is hierarchy among concepts (topology) and if a concept is related to another by connecting words (structural).

- Content: it checks if the focal question was answered, if the concepts chosen are necessary to explain the question, if the propositions also have quality, completeness, relevance and if there are examples.

These criteria were organized into a table created by the researcher and, for each criterion, the answer "yes" or "no" was assigned (FIGURE 1).

\begin{tabular}{|l|}
\hline \multicolumn{2}{|c|}{ GRAPHICAL } \\
\hline Topology|Structural \\
\hline
\end{tabular}$\quad$\begin{tabular}{|l|l|l|l|l|l|l|l|l|}
\hline \multicolumn{7}{|c|}{ CONTENT } \\
\cline { 3 - 9 } & Focal Question & \multicolumn{3}{|c|}{ Concepts } & \multicolumn{3}{c|}{ Propositions } & Examples \\
\hline & & Completeness & Quality & Relevance & Completeness & Quality & Relevance & \\
\hline
\end{tabular}

FIGURE 1 - Image of the table used for concept maps' evaluation.

After the analysis of each concept map, "yes" answers were added and the map was considered: Excellent (10 “yes" answers), Very Good
(8-9 "yes" answers), Good (6-7 "yes" answers), Regular (5 "yes" answers), Unsatisfactory (3-4 "yes" answers), Insufficient (0-2 "yes" answers).

\section{Results}

As for CM, students' performance can be considered positive since they managed to use it satisfactorily to represent their knowledge, besides showing how they understood the concepts studied.

The following table shows the frequency of each category of CM produced by the students before and after intervention, considering the different levels of quality of CMs described below.

Below, some CMs prepared by students were observed, which were categorized in the previous table, aiming exemplifying each category. 
TABLE 1 - Categories of CM produced by the students before and after intervention.

\begin{tabular}{lcc}
\hline Categories & Pre-intervention & Post-intervention \\
\hline Not done & $2,04 \%(\mathrm{n}=1)$ & $4,08 \%(\mathrm{n}=2)$ \\
Insufficient & $2,04 \%(\mathrm{n}=1)$ & $2,04 \%(\mathrm{n}=1)$ \\
Unsatisfying & $12,24 \%(\mathrm{n}=6)$ & $14,28 \%(\mathrm{n}=7)$ \\
Regular & $8,16 \%(\mathrm{n}=4)$ & $14,28 \%(\mathrm{n}=7)$ \\
Good & $32,65 \%(\mathrm{n}=16)$ & $14,28 \%(\mathrm{n}=7)$ \\
Very good & $30,61 \%(\mathrm{n}=15)$ & $28,57 \%(\mathrm{n}=14)$ \\
Excellent & $12,24 \%(\mathrm{n}=6)$ & $22,44 \%(\mathrm{n}=11)$ \\
\hline
\end{tabular}

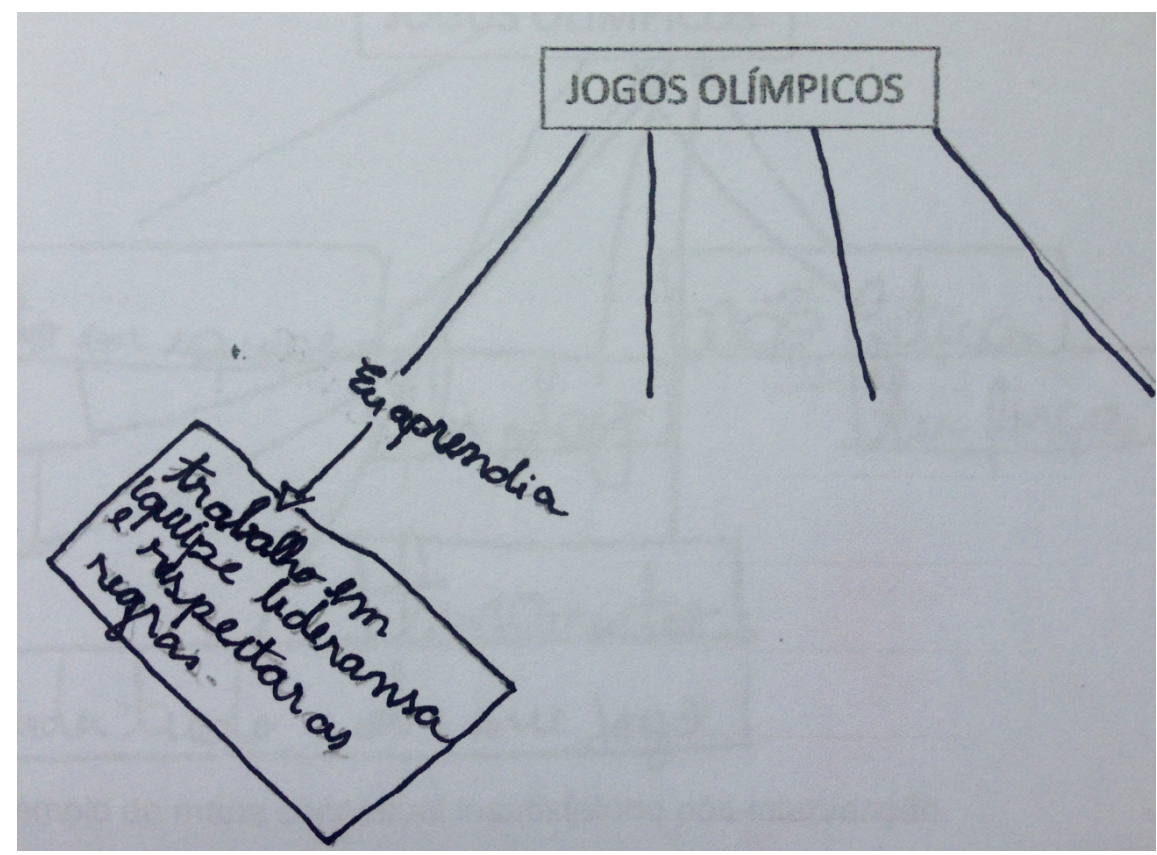

FIGURE 2 - Insufficient CM post-intervention.

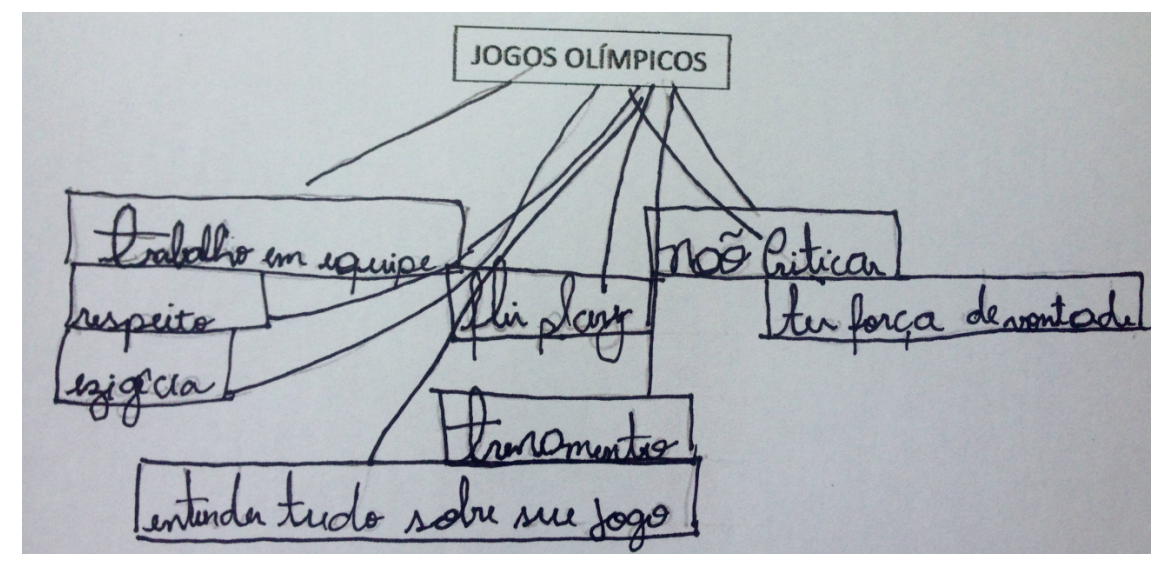

FIGURE 3 - Unsatisfying CM post-intervention. 


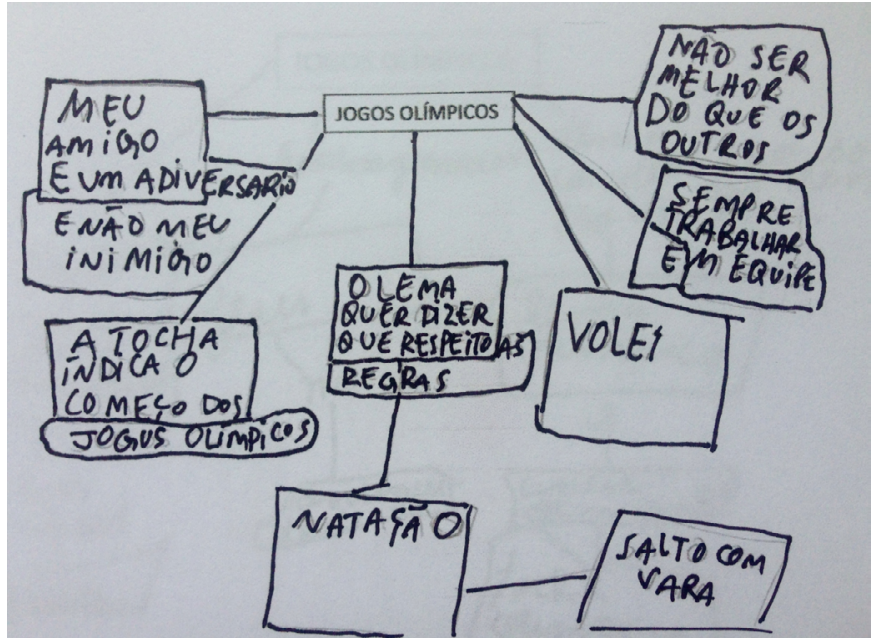

FIGURE 4 - Regular CM post-intervention.

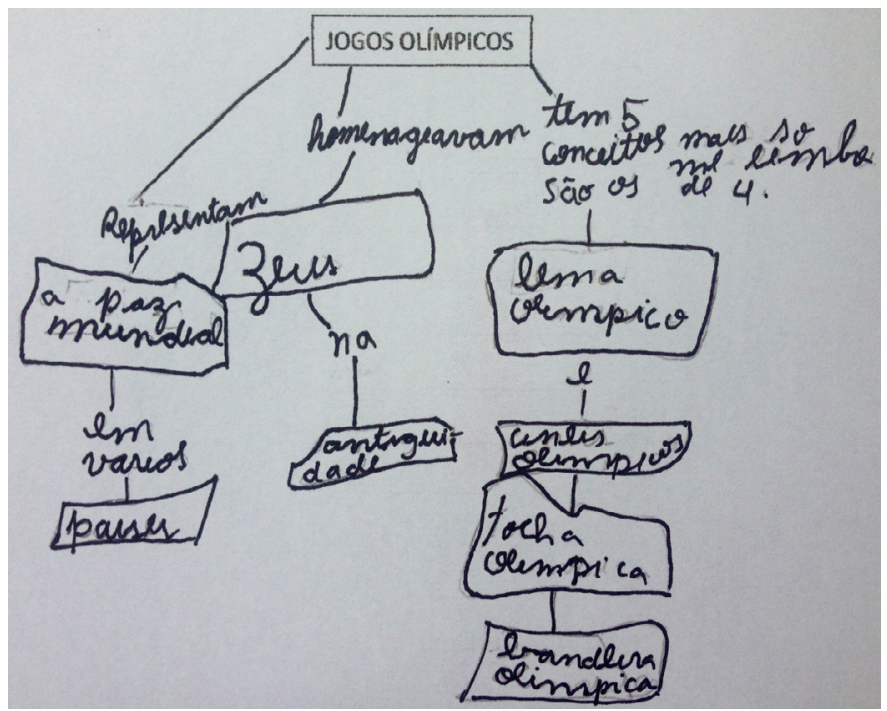

FIGURE 5 - Good CM post-intervention.

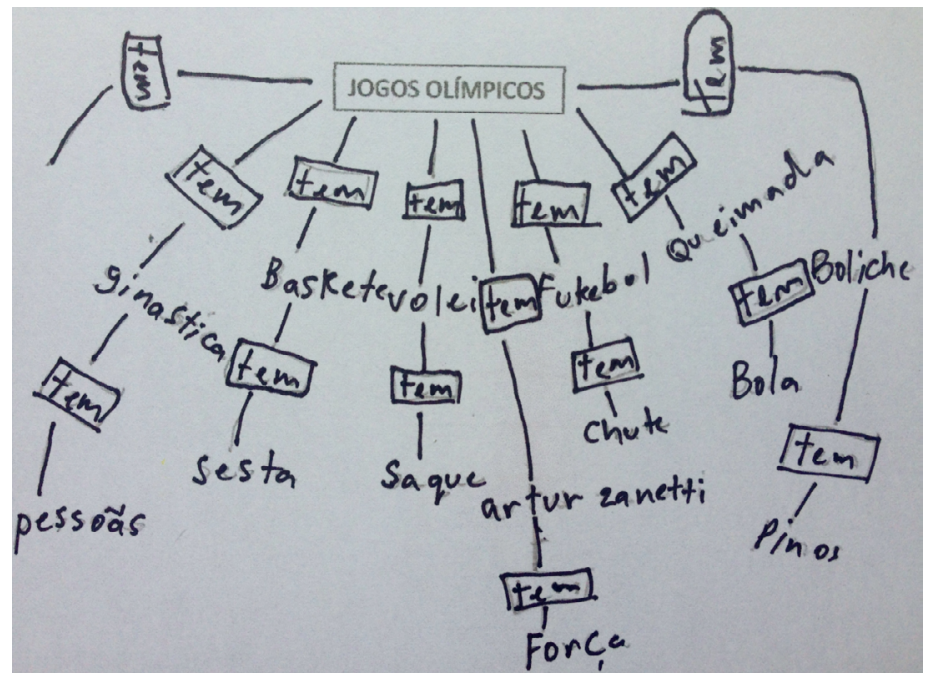

FIGURE 6 - Very Good CM post-intervention. 


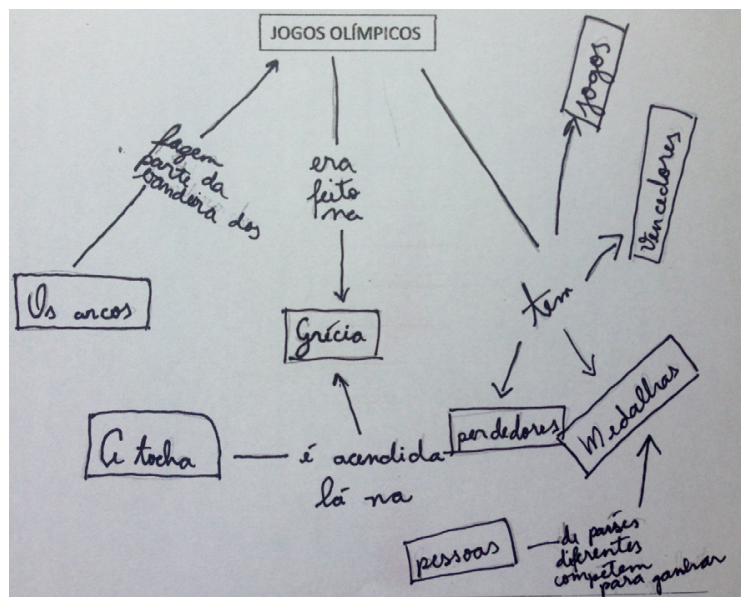

FIGURE 7 - Excellent CM post-intervention.

The maps also allowed collecting qualitative data on the meaning attributed to the Olympic Games by students as well as conceptual errors. Examples of some maps, whose propositions were transformed into sentences, will be presented in the next table. These data help to shape subsequent actions of teachers, because they have, in hand, the type of representation that the students have about knowledge (TABLE 2).

TABLE 2 - Examples of proposition representing conceptual error or meaning attributed.

\begin{tabular}{llcc}
\hline Category & \multicolumn{1}{c}{ Exemple of proposition } & Conceptual errors & Meaning attributed \\
\hline Insufficient & $\begin{array}{l}\text { "Olympic Games I learned teamwork, } \\
\text { leadership and respect the rules." }\end{array}$ & $\mathrm{X}$ \\
Good & $\begin{array}{l}\text { "Olympic Games represents world peace." } \\
\text { Very good }\end{array}$ & $\mathrm{X}$ & $\mathrm{X}$ \\
Excellent & "Olympic Games has dodgeball"; & & $\mathrm{X}$ \\
\hline
\end{tabular}

Other qualitative data to be extracted from the map is the way students changed the understanding of concepts. It can be observed in the comparison between maps before and after intervention. The propositions were transformed into sentences, as in the examples of conceptual errors and meaning attributed and although some conceptual errors still appear after intervention, it is possible to observe the presence of new concepts, examples and elaborated propositions with other linking words, showing an improvement in the understanding of concepts related to the Olympic Games. The TABLE 3 shows some examples.

TABLE 3 - Pre- and post-intervention proposition's examples.

\begin{tabular}{lll}
\hline Student & \multicolumn{1}{c}{ Pre-intervention } & \multicolumn{1}{c}{ Post-intervention } \\
\hline 20A & Arthur Zanetti joined the Olympic Games; & Olympic Games are games; \\
& Brazil went to Olympic Games; & Games like basketball and gymnastics; \\
& US went to Olympic Games; & Arthur Zanetti is gymnastics; \\
& Olympic Games has basketball; & Arthur Zanetti has strength; \\
& Olympic Games has swimming; & Arthur Zanetti and Cesar Cielo are athletes; \\
Olympic Games has pole vault; & Cesar Cielo swim. \\
Olympic Games has soccer; & \\
There's Paralympic in the Olympic Games; & \\
Women's volleyball is a game of volleyball with girls & \\
at the Olympic Games; & \\
Arthur Zanetti competed with athletes in the gym. &
\end{tabular}


Contiuation

TABLE 3 - Pre- and post-intervention proposition's examples.

\begin{tabular}{|c|c|c|}
\hline Student & Pre-intervention & Post-intervention \\
\hline $11 \mathrm{C}$ & $\begin{array}{l}\text { Olympic Games has sports; } \\
\text { Olympic Games has basketball; } \\
\text { Olympic Games has soccer; } \\
\text { Olympic Games has diving; } \\
\text { Olympic Games has synchronized swimming. }\end{array}$ & $\begin{array}{l}\text { Olympic Games has collaboration; } \\
\text { Olympic Games has rings; } \\
\text { Olympic Games has swimming; } \\
\text { Swimming is a sport; } \\
\text { Olympic Games has games; } \\
\text { Olympic Games has teamwork; } \\
\text { Olympic Games has friendship; } \\
\text { Olympic Games has sports. }\end{array}$ \\
\hline $7 D$ & $\begin{array}{l}\text { Olympic Games has net and ball; } \\
\text { Olympic Games has soccer, ball and basket; } \\
\text { Olympic Games has golden and silver medals; } \\
\text { Olympic Games have gymnastic, ping-pong and } \\
\text { volleyball. }\end{array}$ & $\begin{array}{l}\text { Olympic Games has run, runners, balls, me- } \\
\text { dals and sports; } \\
\text { Olympics was a tribute to Zeus; } \\
\text { In the Olympic Games, whoever wins, wins } \\
\text { silver medal, gold medal. }\end{array}$ \\
\hline $8 D$ & $\begin{array}{l}\text { Olympic Games has athletics and swimming; } \\
\text { Volleyball and basketball are in the Olympic Games; } \\
\text { Pique-bandeira* and dodgeball aren't in the } \\
\text { Olympic Games. } \\
\text { * The children have to cross the enemy territory and } \\
\text { take the opponent's flag without letting them catch } \\
\text { the flag of their team. }\end{array}$ & $\begin{array}{l}\text { Olympic games are a competition; } \\
\text { Competition has swimming, soccer and basket- } \\
\text { ball; } \\
\text { Olympic games are sports; } \\
\text { Sport is a game that takes place from } 2 \text { to } 2 \\
\text { years**; } \\
\text { It turns } 2 \text { in } 2 \text { years and has many athletes. } \\
{ }^{* *} \text { student's conceptual error. }\end{array}$ \\
\hline
\end{tabular}

Following the analyses, the students who had compared pre and post intervention. The next TABLES propositions that improved the quality of CM, were $(4,5,6,7$ and 8$)$ presents these propositions:

TABLE 4 - Pre- and post-intervention proposition's examples from student 1A who improved their CM.

\begin{tabular}{lccl}
\hline & $\begin{array}{c}\text { Student 1a } \\
\text { Pre-intervention }\end{array}$ & CM evaluation \\
\hline Initial concept & Link & Final concept & \\
\hline Olympic Games & the flag has & 5 rings & basketball \\
Olympic Games & has & swimming & Good \\
Olympic Games & has & London & \\
The last OG were & in & basketball & \\
The players & of & London & CM evaluation \\
swimming & was in & & \\
& Pre-intervention & Final concept & Excelent \\
\hline Initial concept & Link & swimming & \\
\hline Olympic Games & has & a sport & \\
Swimming & is & the 5 rings & \\
Olympic Games & the symbol is & 5 countries & \\
the 5 rings & represents & hin 4 years & \\
Olympic Games & happen & &
\end{tabular}


TABLE 5 - Pre- and post-intervention proposition's examples from student 3A who improved their CM.

\begin{tabular}{lccc}
\hline & $\begin{array}{c}\text { Student 3a } \\
\text { Pre-intervention }\end{array}$ & CM evaluation \\
\hline Initial concept & Link & Final concept & \\
\hline Olympic Games & - & Began an ancient Greece & Insufficient \\
\hline Post-intervention & CM evaluation \\
\hline Initial concept & Link & Final concept & \\
Olympic Games & - & competition & \\
Competition & - & respect & Unsatisfactory \\
respect & - & as a team & \\
as a team & - & dignity & \\
\hline
\end{tabular}

TABLE 6 - Pre- and post-intervention proposition's examples from student 12A who improved their CM.

\begin{tabular}{|c|c|c|c|}
\hline \multicolumn{3}{|c|}{$\begin{array}{c}\text { Student 12a } \\
\text { Pre-intervention }\end{array}$} & \multirow[t]{2}{*}{ CM evaluation } \\
\hline Initial concept & Link & Final concept & \\
\hline Olympic Games & has & tennis & \\
\hline Olympic Games & has & gymnastics & \\
\hline Olympic Games & Brazil & $\begin{array}{l}\text { won the gold medal with the } \\
\text { volley }\end{array}$ & \\
\hline Olympic Games & has & basketball & \\
\hline Olympic Games & has & run & Good \\
\hline Olympic Games & Arthur Zanetti & won the gold medal & \\
\hline Olympic Games & has & swimming & \\
\hline Olympic Games & has & ping pong & \\
\hline Olympic Games & $\begin{array}{l}15 \text { years old girl from another } \\
\text { country }\end{array}$ & beats the world record & \\
\hline \multicolumn{3}{|c|}{ Post-intervention } & CM evaluation \\
\hline Initial concept & Link & Final concept & \\
\hline Olympic Games & has & run & \\
\hline Olympic Games & has & basketball & \\
\hline Olympic Games & has & rules & \\
\hline Olympic Games & has & fight & Very good \\
\hline Olympic Games & has & volleyball & \\
\hline Olympic Games & has & swimming & \\
\hline Olympic Games & girl & $\begin{array}{l}15 \text { years old beats the } \\
\text { world record }\end{array}$ & \\
\hline
\end{tabular}


TABLE 7 - Pre and post-intervention proposition's examples from student 13A who improved their CM.

\begin{tabular}{|c|c|c|c|}
\hline \multicolumn{3}{|c|}{$\begin{array}{c}\text { Student 13a } \\
\text { Pre-intervention }\end{array}$} & \multirow[t]{2}{*}{ CM evaluation } \\
\hline Initial concept & Link & Final concept & \\
\hline Olympic Games & has & volleyball & \\
\hline Olympic Games & has & swimming & \\
\hline Olympic Games & has & gymnastics & \\
\hline Olympic Games & began & before Christ & Very good \\
\hline Olympic Games & for the first time & were played in Greece & \\
\hline Olympic Games & Brazil won & A gold medal in women's volleyball & \\
\hline Olympic Games & the symbol & 5 rings & \\
\hline \multicolumn{3}{|c|}{ Post-intervention } & CM evaluation \\
\hline Initial concept & Link & Final concept & \\
\hline Olympic Games & Olympic & torch & \\
\hline Olympic Games & has a sport called & weight lifting & \\
\hline Olympic Games & has a sport called & volleyball & \\
\hline Olympic Games & has a Sport called & soccer & Excelent \\
\hline Olympic Games & has a sport called & run & \\
\hline Olympic Games & has & work in teams & \\
\hline Olympic Games & games tributed to & Zeus & \\
\hline
\end{tabular}

TABLE 8 - Pre- and post-intervention proposition's examples from student ${ }_{11 C}$ who improved their CM.

\begin{tabular}{|c|c|c|c|}
\hline \multicolumn{3}{|c|}{$\begin{array}{c}\text { Student 11c } \\
\text { Pre-intervention }\end{array}$} & \multirow[t]{2}{*}{ CM evaluation } \\
\hline Initial concept & Link & Final concept & \\
\hline Olympic Games & has & sports & \multirow{5}{*}{ Insufficient } \\
\hline Olympic Games & has & basketball & \\
\hline Olympic Games & has & soccer & \\
\hline Olympic Games & has & diving & \\
\hline Olympic Games & has & Syncronized swimming & \\
\hline \multicolumn{3}{|c|}{ Post-intervention } & \multirow[t]{2}{*}{ CM evaluation } \\
\hline Initial concept & Link & Final concept & \\
\hline Initial concept & Link & Final concept & \multirow{9}{*}{ Very good } \\
\hline Olympic Games & has & collaboration & \\
\hline Olympic Games & has & swimming & \\
\hline swimming & is a & sport & \\
\hline Olympic Games & has & rings & \\
\hline Olympic Games & has & games & \\
\hline Olympic Games & has & teamwork & \\
\hline Olympic Games & has & sports & \\
\hline Olympic Games & has & friendship & \\
\hline
\end{tabular}




\section{Discussion}

When analyzing data (FIGURES 2 to 7), it was observed that the quality of CMs did not undergo major changes; however, the initial goal was to not only to improve them, but rather to use them as a teaching, learning and assessment tool. It is worth remembering that no class scheduled was focused on the technique to build CMs.

Even if the quality of CMs is not the only objective, it can be inferred that the contact with this tool in some moments of the content block was important because it helped students reinforce what they already knew about CM and especially to cognitively organize concepts. The increased frequency of maps considered excellent (TABLE 1) indicates an improved use of this tool, even if used at other times, not just in the assessment of guiding teaching activities. However, decreasing the frequency of good maps indicates that a class on building CM could be a good strategy to improve its quality.

The low frequency of insufficient and unsatisfactory CM demonstrates that students were not surprised by the presence of the tool, since they were already familiar with its use.

The CM's analysis shows that students improve the quality of the concepts used to describe the Olympic Games. According to their CM pre and post-intervention, they shower greater connectivity, a variety of concepts that involve attitudinal dimensions (respect, dignity, friendship, teamwork, etc.) and better detailed as the description of the Olympic symbols and the sports (TABLES 4 to 8 ).

For example, in TABLE 4, the student identified as $1 \mathrm{~A}$, in the $\mathrm{CM}$ pre-intervention, presented knowledge about the contents of the Olympic Games by citing that the OG's flag has 5 rings and that in OG has basketball and swimming. However, in the post-intervention, besides showing other crosslinks and a more complex graphic representation, he added concepts such as the periodicity of the games and that the five rings represent something related to the countries. Another example that demonstrates improvement in the understanding of the concepts related to $O G$ is on TABLE 8. The student $11 \mathrm{C}$, in his pre-intervention $\mathrm{CM}$, represented that the $\mathrm{OG}$ were characterized by the presence of different sports as basketball, soccer, diving and synchronized swimming. In the CM postintervention, concepts related to attitudinal issues such as cooperation, teamwork and friendship appeared.

The book used with the students for the development of the content block was the "Sport, education and Olympic values", by Katia Rubio. In it the author brings information about the historical context of the OG and various subjects such as Olympic values, legacy, doping and volunteering. It was necessary to choose what would be treated in the content block due to the number of classes.

The TABLE 2 gave us examples of misconceptions and different meanings attributed to a particular concept. When the student says that the OG has burned or that, it presents a misconception. It is up to the teacher to resume with these students what modalities are part of the OG so that the error does not recur. With regard to the different meanings attributed, for example, there is a student who talks about the OG referring to teamwork, leadership and respect for rules; another student says that the OG represent world peace, and a third student says that the OGs are a tribute to Zeus. The three descriptions are correct and point to idiosyncratic factor'.

It's important to remember that, according to CAÑAS and NovAK ${ }^{5}$, we cannot reduce the CM's potential as a tool only as an evaluation tool and what it informs is only part of the educational process. The authors state that the $\mathrm{CM}$ can be evaluated through a graphical and content analysis. However, teachers need to understand that the type and quality of CMs should be more a reflection of the learning process and the conditions under which each of them was built than the exact understanding on the subject.

From the results it is inferred that the CM is an assessment tool that allows assessment changes in the way children understand the concepts studied ${ }^{4,5}$. The teacher can see, more clearly, how students represent knowledge, even if this knowledge presents conceptual error. Although some students do not reach all requirements needed to characterize a $\mathrm{CM}$, the content that brought in the graphical representation of knowledge was relevant and improved after the intervention.

Thus, the teacher can identify which aspects of the concepts involved in the topic under study need reinforcement, significance or widening and deepening. They can also collect information on the maps in the need to explore situations involving problems with exemplification, application, analysis, and evaluation by the students on the concepts studied.

The present study aimed to verify the influence of an instructional planning based on the premises of meaningful learning, which uses concept maps in the learning of concepts in physical education classes. 
The reason for the execution of this study came from an author's concern, who would like to show to the students how much they could learn in physical education classes. To this end, a learning theory that values the cognitive, affective and motor aspects was chosen.

The proposed intervention was planned in real working conditions, which allows it to be applied in various contexts, respecting the characteristics of every environment. Therefore, this study is not an end in itself, but can be a contribution for teachers to organize their practice in a way to value meaningful learning.

Students were prepared for this intervention for almost one year so that the premises of meaningful learning were met. They studied the Olympic Games and met the conceptual maps in other content blocks, thus minimizing the possibility of the occurrence of obvious positive results from the moment that something totally new is taught. They were also minimally familiar with the use of CM in physical education classes, so that difficulties in its use did not impair the learning of the contents proposed.

One possibility for future study is the use of different combinations of teaching techniques with CMs. This gap can be filled with further studies.

It was made clear to students that this activity would not be worth grade. However, they should do the best they could. Knowing that the student's will to learn this way is one of the points where the teacher cannot interfere, the student may not show what he really knows about it, which is a limitation difficult to control.

The selection of the theme in the content block, the Olympic Games, was not made at random, although any topic can be worked from the perspective of meaningful learning. The Olympic Games, theme inserted in Olympic education, brings values and attitudes that could be taught in the schools. According to SHIELds \& BREDEMEIER $^{14}$, the sport is a teaching and learning tool, justified as a path to the development of human values and considered a character builder, however, this issue receives little empirical investigation. Authors as CANNON et al. ${ }^{15}$ considered that teaching values in sport is not simple due to its subjectivity and coaches and physical educators must implement appropriate learning experiences to promote the value.

In addition, the pilot study took place in an Olympic year (2012) and because Rio de Janeiro would be the next host city of the Olympic Games, it was considered that the context is favorable and it is necessary for students to acquire knowledge on this subject so that they can enjoy, appreciate and intervene with this sports event, agreeing with one of the requirements proposed by Ferraz \& MACEDo ${ }^{8}$ which aims to be a critical consumer of physical activities practices.

Physical education can benefit itself from the potential of the CM as a teaching, learning and assessment tool. As this discipline not only provides the opportunity for students to express themselves physically, to face various predicaments, such as failure, success, interpersonal conflict, to acquire relevant knowledge on body movement culture (games, sports, gymnastics, dances and fight), but it also appropriately combines the essential triad of thinking, feeling and acting for the success of Educational Theory Novak.

However, it is important to highlight that an instructional planning that meets the demands of Novak's Theory of Education must be constantly revised in order that the gaps can be fulfilled and meaningful learning achieved by all students.

\section{Resumo}

Aprendizagem significativa e o ensino de conceitos na Educação Física escolar: um estudo de caso com os jogos Olimpicos

0 objetivo desta pesquisa foi investigar a influência de um planejamento instrucional baseado nas premissas da aprendizagem significativa, a partir dos princípios da Teoria Educacional de Joseph D. Novak, utilizando mapas conceituais e outros recursos didáticos na aprendizagem de conceitos em aulas de educação física. Os alunos fizeram um mapa conceitual pré e pós-intervenção. A análise dos resultados mostrou que houve melhoria na qualidade dos mapas conceituais e no entendimento de conceitos relacionados aos Jogos Olimpicos, organizados sob os principios da Teoria Educacional de Novak e que novas ferramentas de ensino e aprendizagem deveriam fazer parte das aulas de educação física.

Palavras-Chave: Teoria educacional; Mapas conceituais; Teoria Educacional de Novak; Ferramentas de aprendizagem. 


\section{References}

1. Coll C, Pozo JI, Sarabia B, Valls E. Os conteúdos na reforma: ensino e aprendizagem de conceitos, procedimentos e atitudes. Porto Alegre: Artmed; 2000.

2. Novak JD. Learning, creating, and using knowledge. 2nd ed. New York: Routledge; 2012.

3. Ausubel DP, Novak JD, Hanesian H. Psicologia Educacional. Rio de Janeiro: Interamericana; 1980.

4. Novak JD, Cañas AJ. The universality and ubiquitousness of concept maps. Proceedings of 4th International Conference on Concept Mapping; 2010 Oct 5-7; Viña del Mar, CL. CMC.

5. Cañas AJ, Novak JD. Freedom vs. restriction of content and structure during concept mapping: possibilities and limitations for construction and assessment. In: Concept Maps: Theory, Methodology, Technology. Proceedings of the 5th International Conference on Concept Mapping; 2010 Sep 17-20; Valletta, MT. CMC

6. Li W. The role of conceptions of ability in student cognition. In: Housner LD, Metzler MW, Schempp PG, Templin TJ. Historic traditions and future directions of research on teaching and teacher education in physical education. Morgantown: Fitness Information Technology; 2009.

7. Ferraz APCM, Belhot RV. Taxonomia de Bloom: revisão teórica e apresentação das adequaçôes do instrumento para definição de objetivos instrucionais. Gest Prod. 2010;17(2):421-31.

8. Ferraz OL, Macedo L. Reflexóes de professores sobre a educação física na educação infantil incluindo o referencial curricular nacional. Rev Paul Educ Fís. 2001;15(1):83-102.

9. Perez CR, Zimmermann MA, Quintilio NK, Marconi JR. Olympic education: reports of a Brazilian reality. In: ICCSPE. The Olympics and Paralympics in Brazil: who takes the prize. Berlin: ICCSPE; 2016.

10. Müller, N. Olympic education. Barcelona: Centre d'Estudis Olímpcs i de l'Esport de la UAB; 2010.

11. Moreira MA, Masini EFS. Aprendizagem significativa: a teoria de David Ausubel. São Paulo: Centauro; 2005.

12. Moura MO, Araujo ES, Ribeiro FD, Panossian ML, Moretti VD. A atividade orientadora de ensino como unidade entre ensino e aprendizagem. In: Moura MO. A atividade pedagógica na teoria histórico-cultural. Brasília: Liber Livros; 2010. p. 81-109.

13. Toigo AM, Moreira MA, Costa SSC. Revisión de la literatura sobre el uso de mapas conceptuales como estratégia didáctica y de evaluación. Investigaçóes em Ensino de Ciências. 2012;17(2):05-39.

14. Shields DL, Bredemeier BL. Moral development and behavior in sports. In: Singer RN, Nausenblas HA, Janelle CM. Handbook of sport psychology. New York: Wiley; 2001. p. 585-603.

15. Cannon HM, Cannon JN, Geddes BC, Feinstein AH. Teaching values: an experiential approach. Developments in Business Simulation and Experiential Learning. 2016;43:273-83.

ADDRESS
Natália Kohatsu Quintilio
School of Physical Education and Sport
University of São Paulo
Av. Prof. Melo Moraes, 65
05508-o3o - São Paulo - SP - BRAZIL
e-mail: nataliakq@usp.br, nataliakq@hotmail.com

Submitted: 05/30/2015

1st. Review: 02/06/2017

Accepted: 06/19/2017 